\title{
Analysis of Technological Developments in the Treatment of Alzheimer's Disease through Patent Documents
}

\author{
Karinne Marieta Carvalho1* ${ }^{*}$, Eduardo Winter ${ }^{2}$, Adelaide Maria de Souza Antunes ${ }^{1,2}$ \\ ${ }^{1}$ School of Chemical, Technology Center, Federal University of Rio de Janeiro, Rio de Janeiro, Brazil \\ ${ }^{2}$ INPI-Brazilian National Institute of Industrial Property, Intellectual Property Academy, Rio de Janeiro, Brazil \\ Email: ${ }^{*}$ karinnemarieta@gmail.com, winter@inpi.gov.br, adelaide@eq.ufri.br
}

Received 15 August 2015; accepted 26 September 2015; published 29 September 2015

Copyright (C) 2015 by authors and Scientific Research Publishing Inc.

This work is licensed under the Creative Commons Attribution International License (CC BY). http://creativecommons.org/licenses/by/4.0/

(c) (i) Open Access

\begin{abstract}
Population aging and the consequent change in the profile of the age pyramid are already a reality the world over. One undeniable effect of this aging process is the significant increase in the number of people with Alzheimer's disease (AD), which is the most common form of dementia, accounting for around $50 \%-60 \%$ of all cases. AD tends to affect people in their $60 \mathrm{~s}$, becoming progressively more commonplace in older age groups. It is an incurable disease, and patients can live for many years taking medication on a daily basis. This study shows that research into AD is on the rise around the world because the pharmaceutical industry and research institutions are seeking new types of drugs to treat and even cure Alzheimer's patients. By analyzing patent documents, we map out the potential future treatments for this disease, indicating the leading countries and drugs companies that have invested most in a bid to accelerate progress towards new discoveries about the disease and the development of new drugs.
\end{abstract}

\section{Keywords}

Patents, Alzheimer's Disease, Drugs, Population Aging, Pharmaceutical Industry

\section{Introduction}

Population aging is a global phenomenon, as developing countries start to see their average life expectancy rising to levels similar to those of developed countries in Europe and North America, where 22\% of the population

"Corresponding author.

How to cite this paper: Carvalho, K.M., Winter, E. and de Souza Antunes, A.M. (2015) Analysis of Technological Developments in the Treatment of Alzheimer's Disease through Patent Documents. Intelligent Information Management, 7, 268281. http://dx.doi.org/10.4236/iim.2015.75022 
is already 60 years of age or over (on average). This worldwide demographic trend (Figure 1) has a direct impact on the disease profile with the burden of age-related degenerative diseases clearly on the rise. It is estimated that some 115.4 million people will be living with dementia by 2050 [1].

According to data published by Alzheimer's Disease International, 2014 [3], the number of people with the disease is set to rise faster in developing countries than in developed countries, as it is there that life expectancy has risen most significantly in recent years. This change in the global panorama is also influenced by significant changes in the epidemiological profile, and marked by reduced mortality from infectious and parasitic diseases and an increase in chronic and degenerative diseases. In developed countries, the number of old people is relatively stable (Figure 2). Data on Alzheimer's disease (AD) alone show that it currently affects around 33.9 million individuals worldwide [4].

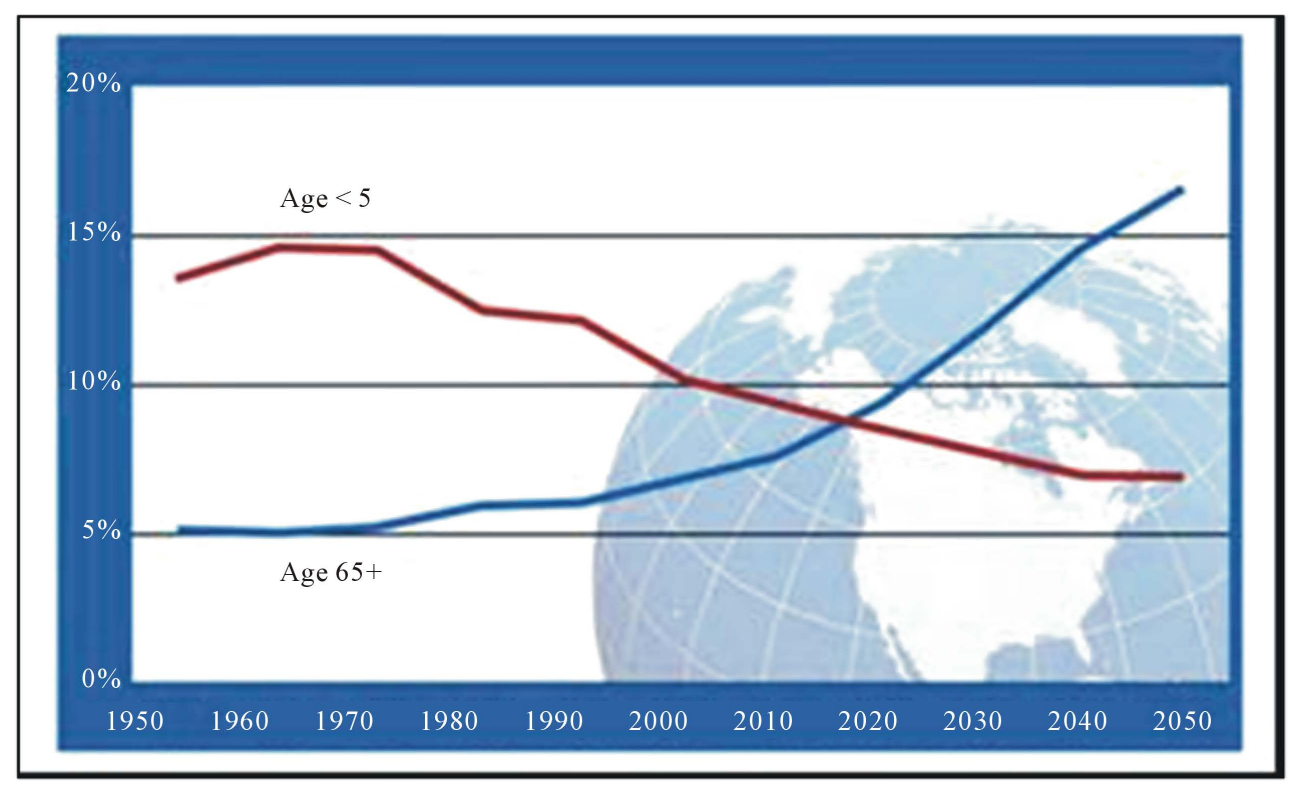

Figure 1. Young children and older people as a percentage of global population: 1950-2050 [2].

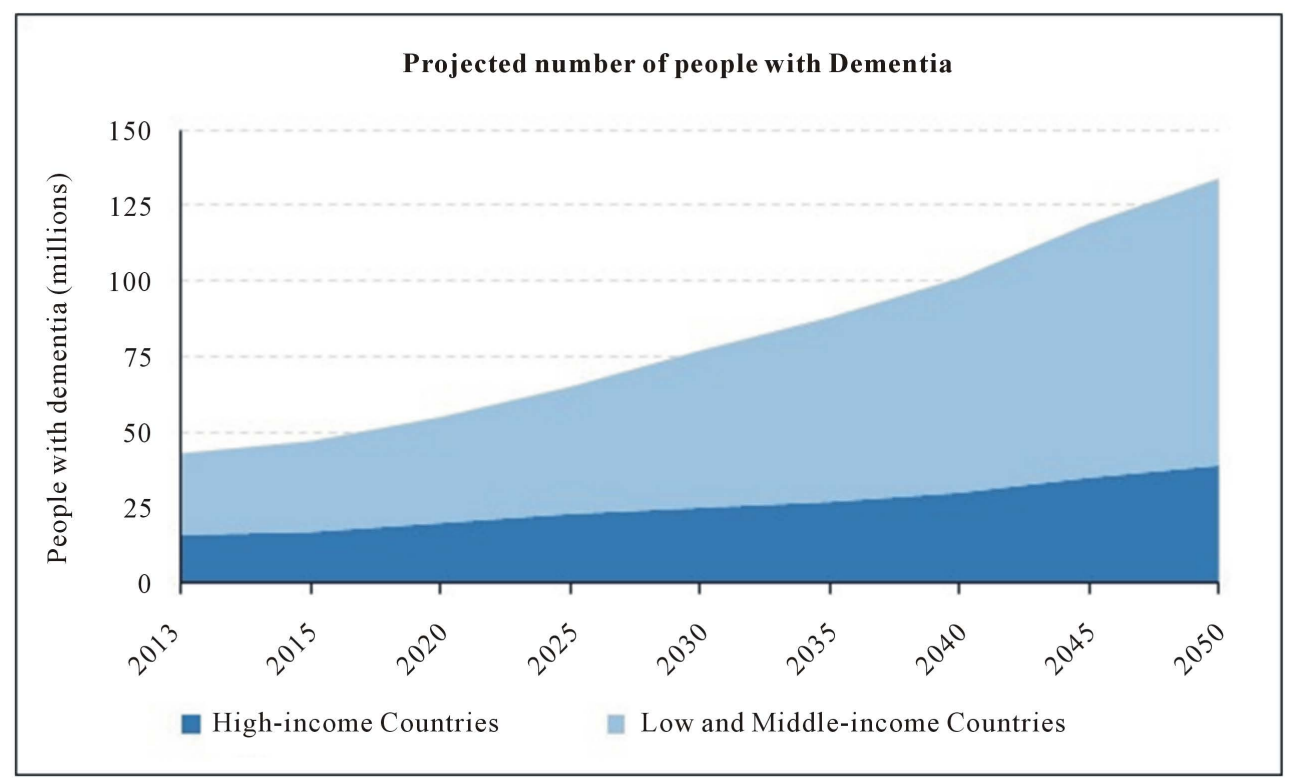

Figure 2. Projected growth of number of people with dementia in low/middle-income and high-income countries [3]. 
As this is an incurable condition that is associated with increased life expectancy and external factors, not all of which have been fully identified, Alzheimer's disease is one of the most significant and challenging areas of biomedical research in the world today. In view of the fact that a high and rising proportion of the population, especially old people, is likely to suffer from this disease [5], and investments are much needed to develop new diagnostic methods, treatments, and preventions, as well as public policies to support these developments.

The risk is real to anyone over the age of 65 : $5 \%$ of people over this age have $\mathrm{AD}$, and this figure rises to $40 \%$ amongst the over-80s [6]. These data demonstrate the importance of having specific public policies for the aging population, because this means more Alzheimer's patients. The quest for treatments for these people is fertile terrain for the pharmaceutical industry. This is why it is so important for studies to appraise the developments underway in this area of health so as to identify the main advances in treatments for the disease and the development trends in different branches of technology, as well as any shortcomings in existing treatments and issues hampering the development of new drugs, thereby offering a significant quantity of information essential to the areas of science directly or indirectly involved in this technology.

\subsection{Alzheimer's Disease}

More than a century ago, a German doctor called Alois Alzheimer (1864-1915) discovered lesions in the brain of a patient that had never been observed before. In a 1907 publication he reported a case of impaired brain function that caused dementia [7]. The problem had to do with atrophied neurons in different parts of the brain, which was full of plaques and fibers twisted into one another. Since then, deposits of this kind have come to be called senile plaques and neurofibrillary tangles, and are tell-tale signs of Alzheimer's disease [8]. These plaques have a toxic effect on neurons, causing their death [9]. With neuronal death comes dementia-the progressive impairment of cognitive function, mainly affecting memory, thinking, and concentration. When the symptoms worsen, other brain functions are also affected, like movement [10]. Amyloid plaques, present in people with $\mathrm{AD}$, are formed by the build-up of beta-amyloid peptide [11], which aggregates to form amyloid plaques that are deposited on the outside of neurons [9]. Neurofibrillary tangles, also a feature of the disease, are formed when tau proteins accumulate in the neuronal cytoplasm [12]. This protein is involved in the stabilization of microtubules in the neuronal cytoskeleton. In $\mathrm{AD}$, the tau proteins are structurally altered and form neurofibrillary tangles [13], which are deposited inside neurons and cause neuronal death (Figure 3).

It has been shown that the beta-amyloid plaques attached to the outside of neurons affect the activity of kinase enzymes, which consequently add an excessive quantity of phosphate to the tau protein, triggering alterations in it and the formation of fibrillary tangles and their build-up inside neurons [7] [15]. These tangles are toxic and cause neuronal death. When this occurs, acetylcholine neurotransmitter levels fall, impairing cognitive function [12].

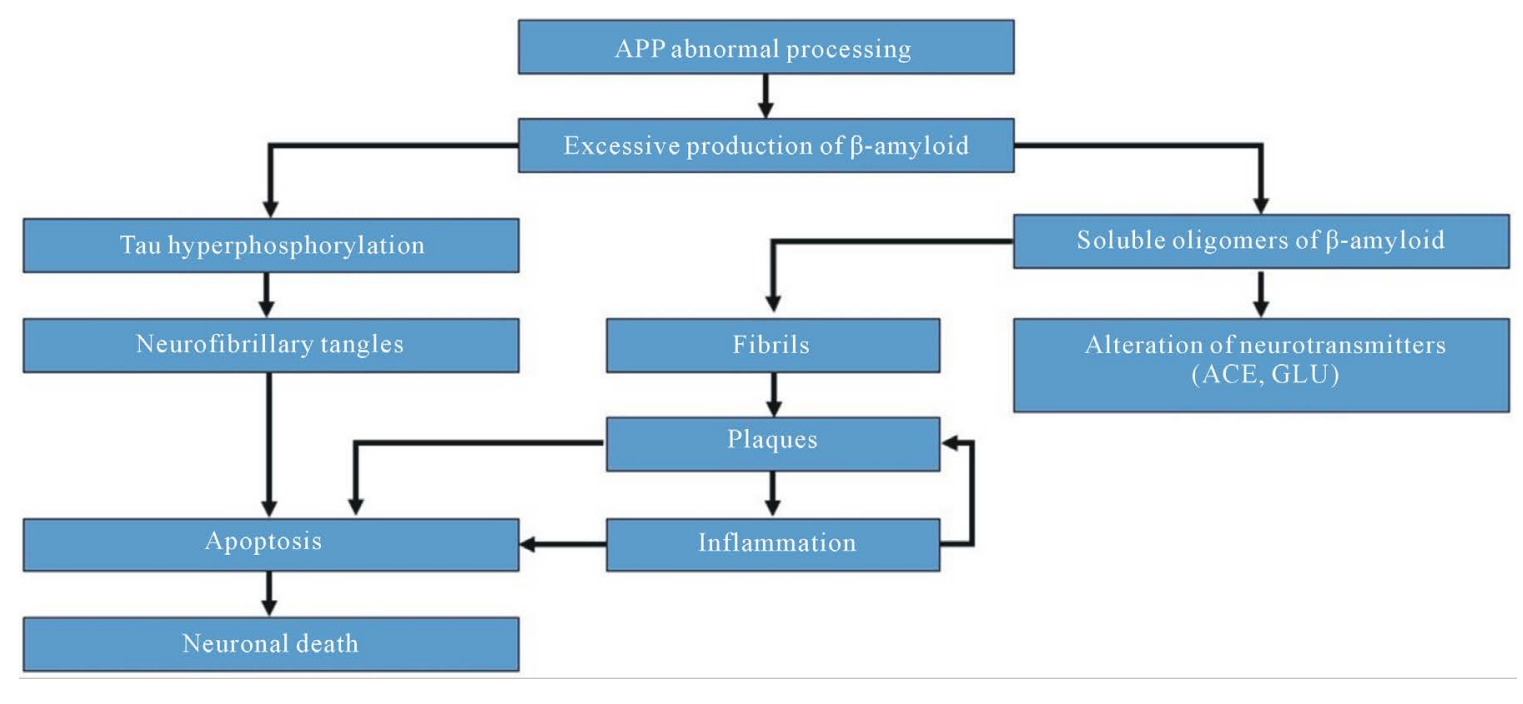

APP: Amyloid Precursor Protein ACE: Acetylcholine GLU: Glutamate

Figure 3. Etiology of Alzheimer’s disease. Adapted from [14]. 
AD is now recognized as a public health issue [16], and has kindled considerable interest in the drug industry because it affects one in ten individuals over 65 years, develops spontaneously, is age-dependent, can affect anybody, is incurable, and the patient can live for years with the disease taking medication on a daily basis. Around the world, the number of Alzheimer's patients is on the rise, driving the need for new research. A good deal has already been discovered about the molecular biology of brain function in neurodegenerative diseases, and many studies have made progress in identifying the causes of the defective protein folding that leads to the production of amyloid plaques, which will surely trigger the discovery of new targets and therapeutic agents. It is hoped that treatments will improve significantly as new mechanisms involved in the pathogenesis are discovered.

\subsection{Medications Available for Alzheimer's Disease}

As Alzheimer's disease is a major health issue that is only likely to increase with time (around 4.6 million new cases are reported each year [17], the primary objective of researchers has been to discover more effective drugs to treat it. Many already exist, but no treatment has yet been found to reverse the progression of the disease or to check the neurodegenerative process [18].

The first medication approved by the U.S. Food and Drug Administration [19] for Alzheimer's disease was tacrine, launched in 1993 [20], whose mechanism consisted of preventing the little remaining acetylcholine from being destroyed by the acetylcholinesterase enzyme, which would increase its concentration in the brain. However, because of the strong hepatotoxicity observed [21], this drug was abandoned.

The drugs approved and used for Alzheimer's treatment are shown in Table 1; all are designed to retard and treat its symptoms. They can be split into two groups: anticholinesterases, which enable the production of acetylcholine, and memantine, which is an NMDA (N-methyl-D-aspartate) receptor antagonist that works by regulating the entry of calcium to neurons, reducing neuronal death [22].

The treatments available for AD are not capable of checking the progression of the disease. As such, research centers and drug companies are keen to discover new medications to modify the metabolism of amyloid substance in some way or to prevent the formation of neurofibrillary tangles, which are found in patients' brains and are responsible for the advance of the disease. However, this is an as yet unresolved challenge for science, as the mechanisms involved in the development of AD, although much studied, are not yet fully understood [12] [23].

\section{Method}

In this technology foresight study, we analyzed patent documents for treatments for Alzheimer's disease. The methodology involved searching patent documents because the information they contain provides the best indication of the state of technological innovation in terms of research and development, as they directly reflect the interests of and trends in the pharmaceutical industry. The foresight methodology used in this study involved three stages. First, we selected the most appropriate database for the objectives of this study. We then searched this database and retrieved data on patent applications for drugs to treat Alzheimer's disease. Finally, we pro-

\section{Table 1. FDA-approved drugs for Alzheimer's disease [19].}

\begin{tabular}{|c|c|c|c|}
\hline Drug & Class and Indication & Mechanism of Action & Common Adverse Effects \\
\hline $\begin{array}{l}\text { Donepezil (FDA-approve } \\
\text { in 1996) }\end{array}$ & $\begin{array}{l}\text { Cholinesterase inhibitor prescribed } \\
\text { dto treat symptoms of } \\
\text { mild-to-moderate and } \\
\text { moderate-to-severe AD }\end{array}$ & $\begin{array}{l}\text { Prevents the breakdown of } \\
\text { acetylcholine in the brain }\end{array}$ & Nausea, vomiting, diarrhea \\
\hline $\begin{array}{l}\text { Galantamine } \\
\text { (FDA-approved in 2001) }\end{array}$ & $\begin{array}{l}\text { Cholinesterase inhibitor prescribed } \\
\text { to treat symptoms of } \\
\text { mild-to-moderate AD }\end{array}$ & $\begin{array}{l}\text { Prevents the breakdown of } \\
\text { acetylcholine and stimulates } \\
\text { nicotinic receptors to release more } \\
\text { acetylcholine in the brain }\end{array}$ & $\begin{array}{l}\text { Nausea, vomiting, diarrhea, loss of } \\
\text { appetite, weight loss }\end{array}$ \\
\hline $\begin{array}{l}\text { Rivastigmine } \\
\text { (FDA-approved in 2000) }\end{array}$ & $\begin{array}{l}\text { Cholinesterase inhibitor prescribed } \\
\text { to treat symptoms of } \\
\text { mild-to-moderate AD }\end{array}$ & $\begin{array}{l}\text { Prevents the breakdown of } \\
\text { acetylcholine and butyrylcholine } \\
\text { in the brain }\end{array}$ & $\begin{array}{l}\text { Nausea, vomiting, diarrhea, loss of } \\
\text { appetite, weight loss, muscle weakness }\end{array}$ \\
\hline $\begin{array}{l}\text { Memantine } \\
\text { (FDA-approved in 2003) }\end{array}$ & $\begin{array}{l}\text { N-methyl-D-aspartate antagonist } \\
\text { prescribed to treat symptoms of } \\
\text { moderate-t-severe AD }\end{array}$ & $\begin{array}{l}\text { Blocks the toxic effects associated } \\
\text { with excess glutamate and } \\
\text { regulates glutamate activation }\end{array}$ & $\begin{array}{l}\text { Dizziness, headache, constipation, } \\
\text { confusion }\end{array}$ \\
\hline
\end{tabular}


cessed and analyzed the data retrieved. The different stages are shown in Figure 4.

\subsection{Patents: Steps 1 and 2}

We chose the Derwent Innovation Index (DII) database to search for patent documents, as this is one of the databases that can be accessed from the Brazilian Ministry of Education's CAPES portal. It was picked for this purpose because it is internationally recognized and contains over 11 million patent documents filed, published, and sometimes granted in over 40 countries since 1963. One of its main advantages is that for each patent there is a concise abstract written by an expert on the subject. It is also possible to access the primary patent records, which facilitates the retrieval of all the information.

The strategy used was to search for keywords in the titles and abstracts and the International Patent Classification (IPC) of the claim. The period covered was from 1995 to 2012 because of the 18-month period in which patent applications remain confidential. The keywords used were "Alzheimer" and "drug." The IPC class was selected to pick up patent applications of real interest to the analysis, namely subclass A61P 25/28, which is for drugs for treating neurodegenerative disorders of the central nervous system, e.g. nootropic agents, cognition enhancers, drugs for treating Alzheimer's disease or other forms of dementia.

\subsection{Patents: Steps 3 and 4}

Once retrieved, the patent applications were exported to the VantagePoint ${ }^{\circledR}$ commercial software package, 8.0 version. This text mining tool is very useful for analyzing raw data because it enables large quantities of data to be processed and allows the data to be manipulated so that the information can be harmonized. In the case of patents, one company will often have different names in the assignee or inventors field, but this was standardized at this stage. Another important function is the cleaning filter, which can be used to eliminate any duplicates of documents and terms that cause ambiguity.

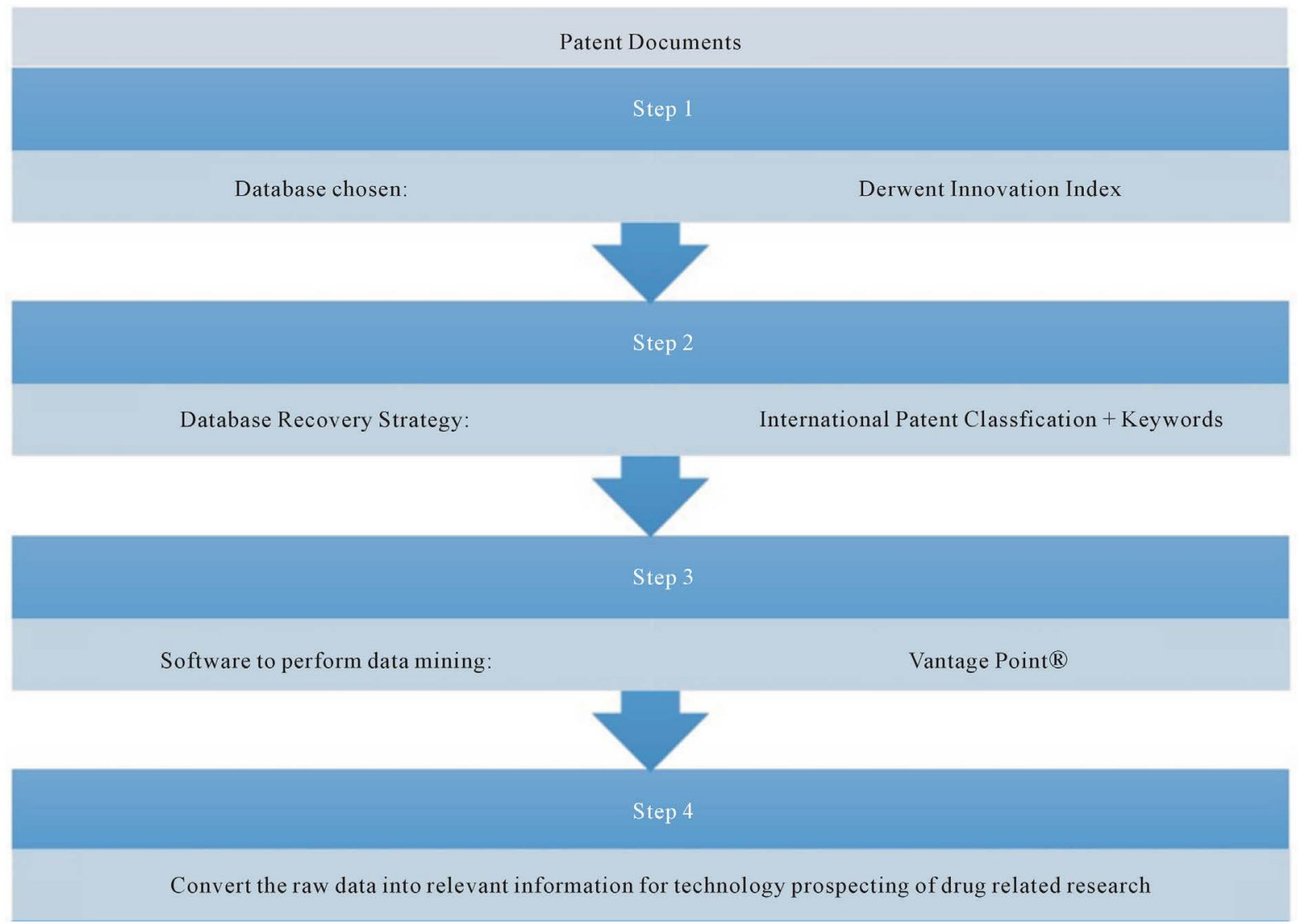

Figure 4. Diagram of the methodology used. 
Having harmonized the data, we were able to extract some basic information on the subject of interest, such as the total number of documents retrieved, the main research areas, and the leading countries and companies in the development of the technology, and could make an analysis of developments in the technology sector.

\section{Results and Discussion}

Using the methodology set forth above, we retrieved 3,919 patent applications for drugs to treat Alzheimer's disease from the DII database. Analyzing these data, we found that the number of patent applications filed in this area first started to grow towards the end of the 1990s, becoming significant in number as of the beginning of this century. A graphic representation of the trend in patent applications for treatments for Alzheimer's disease is given in Figure 5.

We should recall that patent documents are kept confidential for 18 months after they are filed, and there is also a time lag before they are indexed in databases. As such, the 2011 and 2012 figures do not necessarily represent a real drop-off in interest in the area. The number of patents for drugs for Alzheimer's disease treatment has risen in line with the growth in the number of cases around the world. As this is a chronic, incurable condition that normally develops at a slow pace, and patients can take daily medications for 20 years or longer, the drug industry has every interest in researching it [24] and finding more effective treatments with fewer sideeffects or even a cure, thereby ensuring returns on their R\&D investments.

The leading country in this area is the United States (Figure 6). The disease is estimated to cost the country 183 billion dollars, of which the government covers only around 10 billion dollars. The rest is incurred by the patients and their families [25] [26]. Alzheimer's disease affects over 4.5 million people in the USA, and 100,000 people die of it every year [27]. Furthermore, in the most advanced stages of the disease, patients become completely dependent on others and incapable of executing even the simplest of tasks on their own. This has a major economic impact on society, justifying the high investments by the country in research in the area [26].

One important objective of a study of this kind is to find out what the main assignees of the patents in the sector are. Figure 7 shows the main drug companies that invest in AD. Pfizer, which was already a leader in this sector, has consolidated its position further since it acquired Wyeth, a company that also invested heavily in treatments for Alzheimer's disease. In this analysis, Wyeth's patents are counted as Pfizer's.

The drugs approved and used for treating Alzheimer's disease have the capacity to intervene pharmacologically in the cognitive symptoms characteristic of the disease, but the benefits associated with their use are still limited, which is why research into new drugs continues apace. The analysis of the patent documents for AD drugs that already exist on the market shows that they are often for new means of administering and delivering the drugs with fewer side-effects. The significant quantitative results can be seen in Figure 8 .

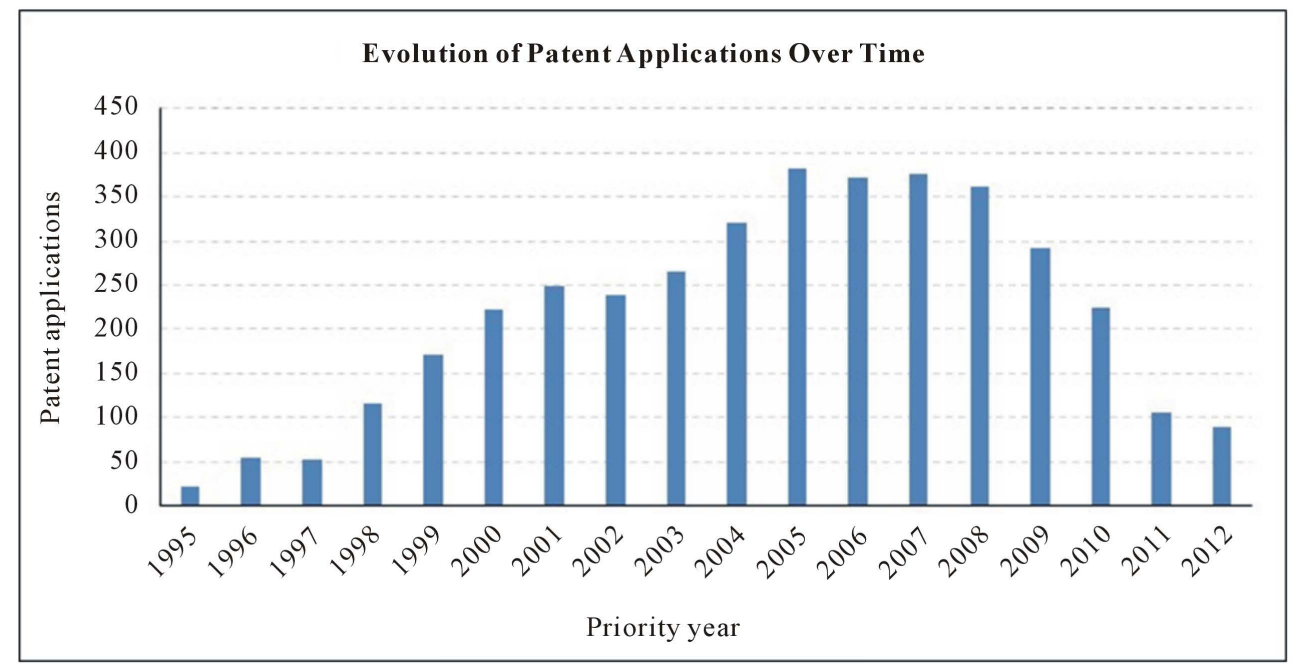

Figure 5. Number of patent applications filed per year for drugs for the treatment of Alzheimer's disease (data from the DII database). 


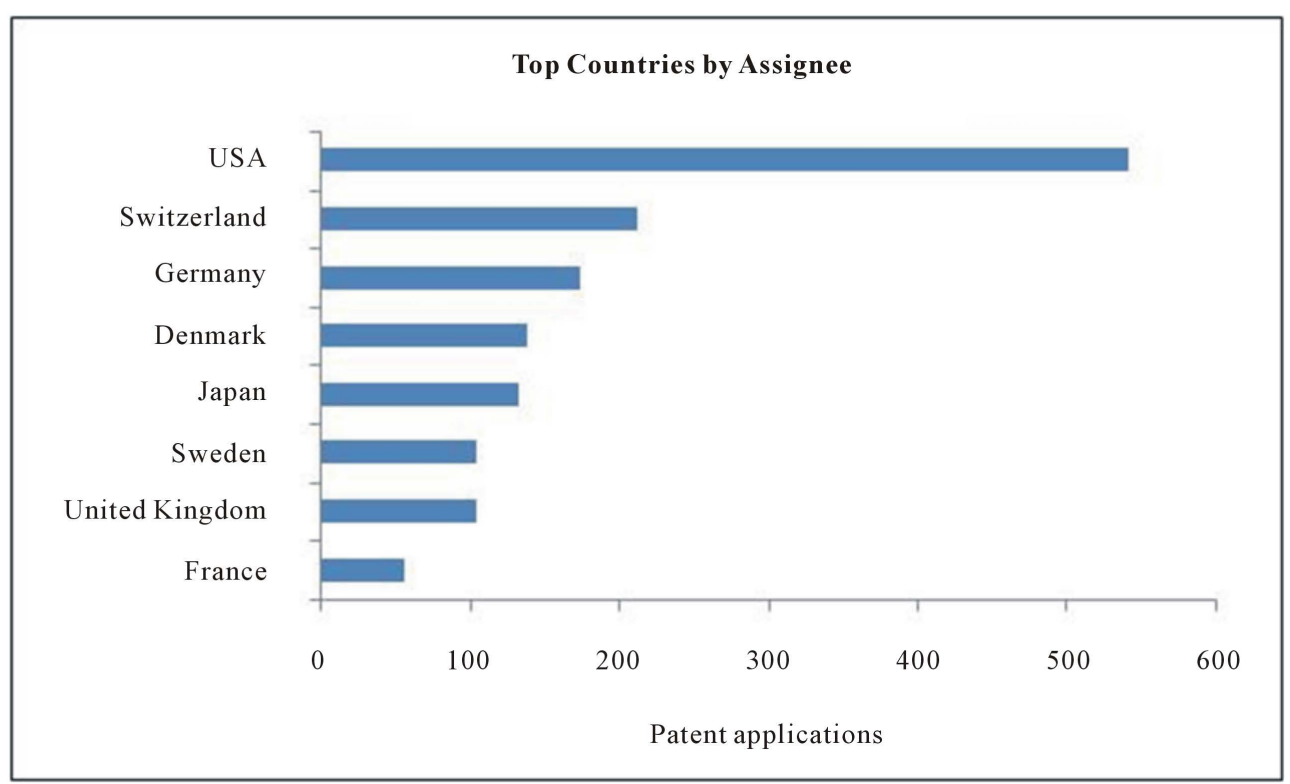

Figure 6. Leading countries where priority patents have been filed (data from the DII database).

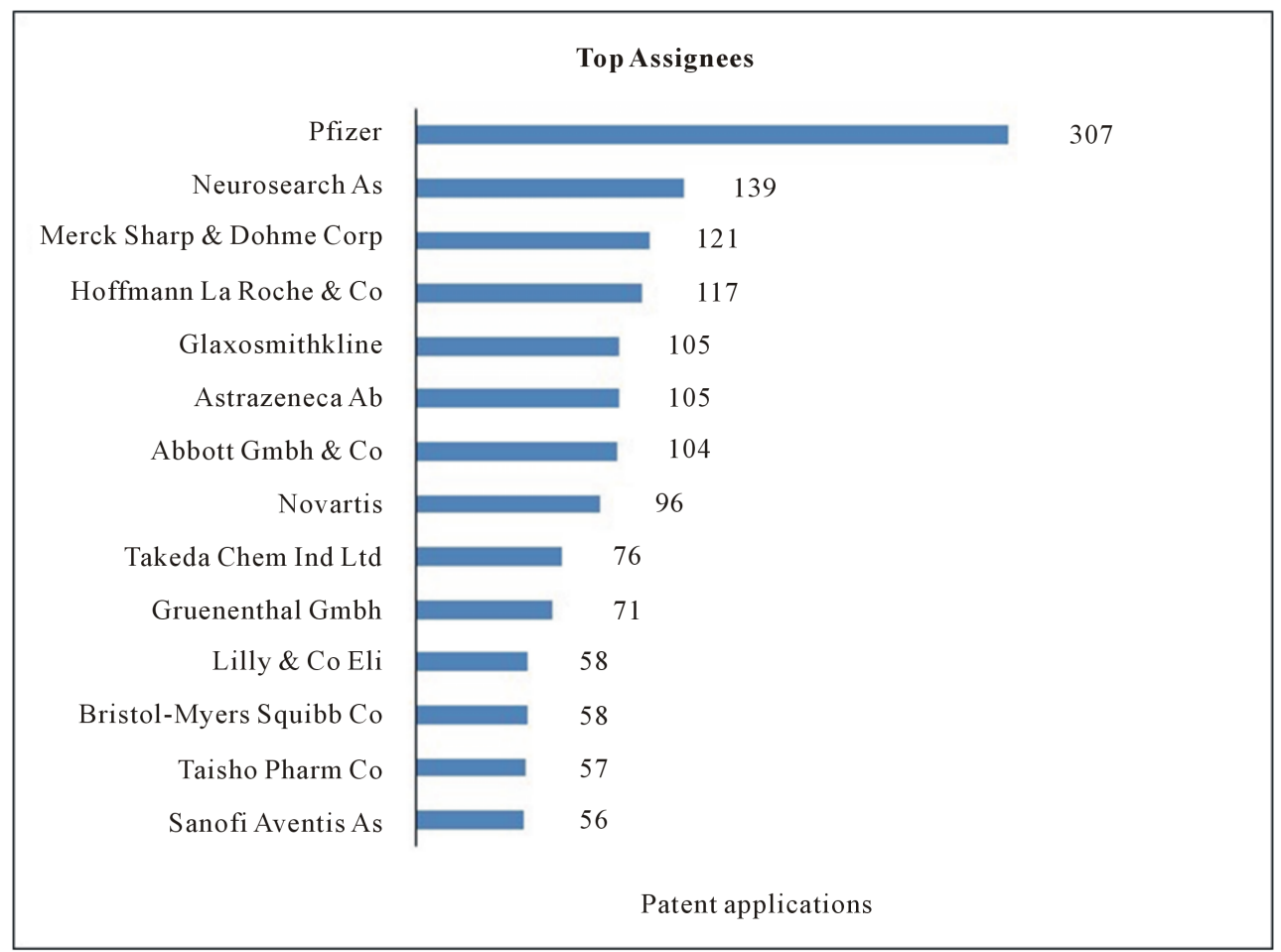

Figure 7. Main assignees of patents filed for drugs for the treatment of Alzheimer's disease (data from the DII database).

Other therapeutic approaches are being researched, some of which are very promising. Much of this research is geared towards finding more effective treatments that retard the progress of the disease or even cure it. It is hoped that drugs capable of modifying the natural evolution of Alzheimer's disease will constitute the next generation of AD treatments [28].

Figure 9 indicates the therapeutic potential of the drugs being studied, tested, and patented around the world with the aim of producing a safe and effective treatment for Alzheimer's patients. 


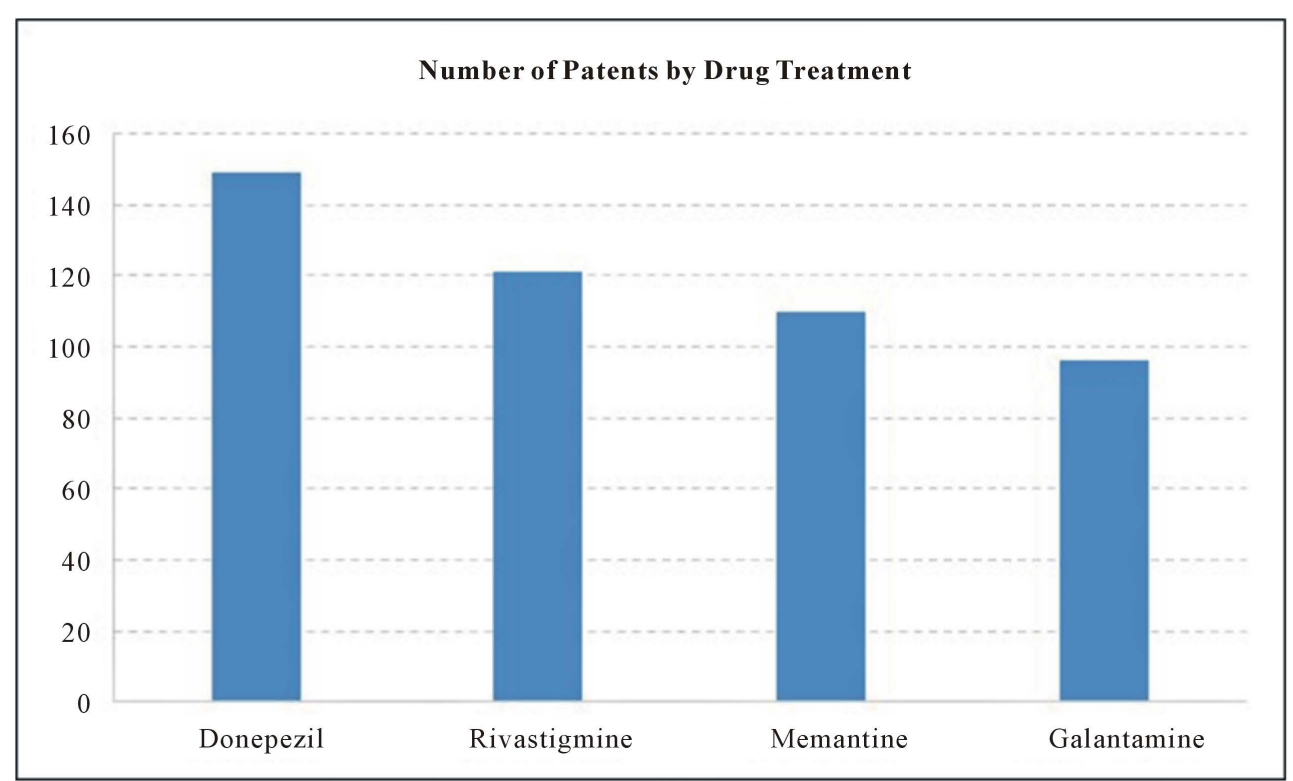

Figure 8. Number of patents per AD drug (information extracted from patent documents retrieved from the DII database).

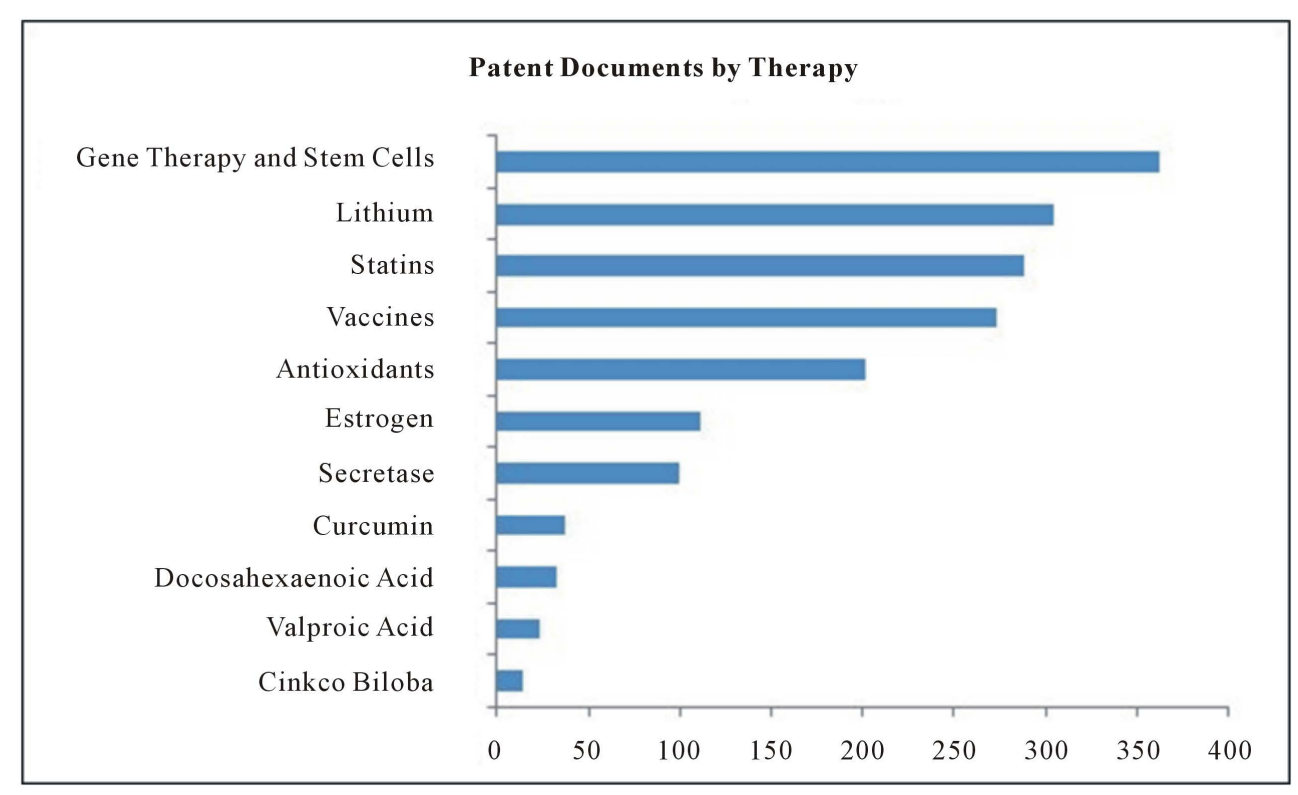

Figure 9. Patent documents per therapy (information extracted from patent documents retrieved from the DII database).

\subsection{Gene Therapy and Stem-Cell Therapy}

There are some drugs currently in use and many under development that are designed to retard the progression of $\mathrm{AD}$, but there is no treatment capable of completely checking its progress. As one of the purposes of stem-cell therapy is to regenerate or replace tissue, this area of study has been cited as a new way forward for future treatments. Research involving the injection of stem cells into areas of the brain that trigger AD symptoms is being conducted [29]-[33], which is consistent with the large number of patents related to this kind of therapy.

Gene therapy, whereby functional genes are introduced into cells with defective genes, is also a promising approach. Experimental and pre-clinical studies have focused on the use of gene therapy for treating AD, bringing new hope for patients [34]-[36]. 


\subsection{Lithium}

Recent studies have shown that lithium salts may exert neuroprotective effects. In in vitro experiments, lithium has been found to improve neuronal viability through a combination of mechanisms, which include the inhibition of apoptosis, regulation of autophagy, increased mitochondrial function, and the synthesis of neurotrophic factors. It is believed that long-term lithium treatment can really retard the progression of cognitive and functional deficits, while also attenuating tau protein hyperphosphorylation, which is implicated in the onset of the disease. Although more research is required in this area, lithium treatment is a promising potential area because it could yield disease-modifying effects [37]-[39].

\subsection{Statins}

Currently used to control cholesterol levels, statins have been studied for their potential in treating Alzheimer's disease because some researchers believe that when statins reduce cholesterol, they may actually alter the metabolism of the beta-amyloid protein precursor, reducing its production and preventing the formation of the plaques responsible for the onset of the disease [40]-[42].

\subsection{Vaccines}

Treatment involving vaccines has also been studied with an eye to preventing or retarding the development of the disease in at-risk individuals before or in the first stages of cognitive decline with the hope of stimulating the immune system to prevent beta-amyloid clumping. It is hoped that such vaccines will clear any build-up of amyloid-beta (abeta) peptides in the brain, inhibiting their neurotoxic action. Immunotherapy involves inoculation with humanized monoclonal antibodies with high specificity to abeta peptides. These antibodies clump together, favoring the elimination of these toxic substances. However, it was found in some trials that the vaccines caused brain inflammation, which is being investigated, since vaccines are still among the most promising therapies for the future [43]-[45].

\subsection{Antioxidants}

One of the likeliest causes of $\mathrm{AD}$ is thought to be oxidative stress. Researchers are therefore trying to find out whether it is possible to improve protection against the disease through the increased ingestion of antioxidants.

Antioxidants can protect brain cells against damage caused by the toxicity of free radicals. Some research is therefore being done into the ingestion of vitamin $\mathrm{E}$, an antioxidant also known as alpha-tocopherol. Vitamin $\mathrm{E}$ has been found to prevent the oxidative damage induced by beta-amyloid in cell cultures, delaying memory deficits in animal models.

Resveratrol, a polyphenol that occurs in abundance in grapes and red wine, also has antioxidant properties, providing neuroprotection. Studies have associated the moderate ingestion of wine with a reduced risk of developing AD. It is believed that resveratrol has powerful anti-amyloidogenic activity.

Other antioxidants also being tested as future drugs are selegiline, vitamin C, selenium, and carotene [46]-[51].

\subsection{Estrogen}

Some studies have associated this sex steroid with Alzheimer's disease, showing that the loss of estrogen associated with menopause could be linked to its development, because estrogen has a major neuroprotective and neuromodulatory role. Using oophorectomized animals, researchers have demonstrated that estrogen induces changes in the metabolism of serotonin in areas of the brain that involve cognition. Although several studies have investigated this effect, there is still a good deal of controversy about the effectiveness of steroids as a treatment for AD [52]-[54].

\subsection{Secretases}

Drugs with other mechanisms are also being researched as potential treatments. There is evidence that substances called secretase inhibitors have the capacity to block beta-amyloid formation. Studies using gamma- and beta-secretases are being done in different parts of the world. These enzymes are believed to be fundamental in the genesis of the beta-amyloid protein. Treatments using these secretase inhibitors could retard the advance of 
the disease, since this process involves reducing the production of beta-amyloid, responsible for the formation of the amyloid plaques that are implicated in the disease [55]-[57].

\subsection{Curcumin}

Curcumin is an anti-inflammatory molecule present in the turmeric root. Epidemiological data demonstrate that there are 4.4 times fewer people in their 70s with AD in India, where turmeric consumption is high, than in the United States. This fact has intrigued the scientific community, and some researchers have demonstrated in in vitro studies that curcumin is indeed capable of fragmenting beta-amyloid plaques. As such, its effect on these plaques is being investigated as a potential future treatment [58]-[60].

\subsection{Docosahexaenoic Acid}

Another possible treatment for Alzheimer's disease is based on docosahexaenoic acid (DHA). This omega-3 polyunsaturated acid encountered in fish and seaweed and is strongly involved in the formation of the cell membranes of nerve cells, especially synaptic membranes. Researchers have found that newborn rats with DHA deficit present a low cognitive performance, and demonstrate space and time disorientation and impaired learning capacity and memory. It has been shown that DHA is an essential fatty acid for the development of the fetal brain, and researchers suggest that a diet rich in DHA could provide protection for the brain against the production of beta-amyloid [61]-[63].

\subsection{Valproic Acid}

Recent evidence indicates that valproic acid—a widely used mood stabilizer—has significant neuroprotective potential for Alzheimer's disease. Studies on laboratory animals suggest that valproic acid protects neurons against beta-amyloid protein and the damage induced by glutamate, because it helps stabilize intracellular levels of calcium. These findings suggest that valproic acid is a promising agent for combatting the disease [64]-[66].

\subsection{Ginkgo Biloba}

Some patients seek out unconventional methods to treat the symptoms of Alzheimer's disease. One such treatment is ginkgo biloba, a herb that contains two components believed to have medicinal effects: flavonoids and terpenoids with antioxidant properties. Ginkgo biloba has been used in China for millennia and some studies have associated it with cognitive enhancement. Although some patent documents cite ginkgo biloba as a possible AD treatment, its efficacy is yet to be proven [67]-[69].

\section{Conclusion}

Population aging is a global reality and one of the biggest challenges for public health, since the higher proportion of old people is directly linked to the rising prevalence of little-understood diseases, like Alzheimer's disease. Although $\mathrm{AD}$ affects a relatively high proportion of the population and has been investigated from a number of different angles, there are as yet no treatments capable of effectively altering the progression of the disease. In view of its complexity, the development of more effective, safer therapeutic options is one of the most hotly pursued goals of international biomedical science. Few drugs have been developed for the treatment of the disease, and none is yet capable of preventing its advance or curing it. With a view to meeting the needs of Alzheimer's patients, the drug industry and research centers the world over are seeking out new ways of understanding the disease in order to discover safe, effective drugs. Through this patent analysis we were able to demonstrate the different research underway into substances with neuroprotective, genetic, immunological, antiinflammatory, and antioxidant properties with a view to designing new chemicals with novel properties to serve as more effective treatments. The discovery of drugs capable of modifying the natural progression of the disease and effective mechanisms for its early diagnosis are the future of the treatment of Alzeimer's disease and the source of hope for a cure for its patients.

\section{References}

[1] Prince, M., Bryce, R., Albanese, E., Wimo, A., Ribeiro, W. and Cleusa, P. (2013) The Global Prevalence of Dementia: 
A Systematic Review and Meta-Analysis. Alzheimer's and Dementia, 9, 63-75. http://dx.doi.org/10.1016/j.jalz.2012.11.007

[2] United Nations (2014) World Population Prospects: The 2010 Revision. http://esa.un.org/unpd/wpp

[3] de Vellis, J. (2014) Alzheimer's Disease International. http://www.alz.co.uk/research/statistics

[4] Barnes, D. and Yaffe, K. (2011) The Projected Impact of Risk Factor Reduction on Alzheimer's Disease Prevalence. Lancet Neurology, 10, 819-828. http://dx.doi.org/10.1016/S1474-4422(11)70072-2

[5] National Institute on Aging. http://www.nia.nih.gov/

[6] (2010) Alzheimer's Disease International. https://www.alz.co.uk/research/files/WorldAlzheimerReport2010ExecutiveSummary.pdf

[7] Wippold, F.J., Cairns, N., Vo, K., Holtzman, D.M. and Morris, J.C. (2008) Neuropathology for the Neuroradiologist: Plaques and Tangles. American Journal of Neuroradiology, 29, 18-22. http://dx.doi.org/10.3174/ajnr.A0781

[8] Tiraboschi, P., Hansen, L.A., Thal, L.J. and Corey-Bloom, J. (2004) The Importance of Neuritic Plaques and Tangles to the Development and Evolution of AD. Neurology, 62, 1984-1989. http://dx.doi.org/10.1212/01.WNL.0000129697.01779.0A

[9] Ittner, L.M. and Götz, J. (2011) Amyloid- $\beta$ and Tau-A Toxic pas de deux in Alzheimer's Disease. Nature Reviews Neuroscience, 12, 67-72. http://dx.doi.org/10.1038/nrn2967

[10] Qiu, C., Kivipelto, M. and von Strauss, E. (2009) Epidemiology of Alzheimer's Disease: Occurrence, Determinants, and Strategies toward Intervention. Dialogues in Clinical Neuroscience, 11, 111-128.

[11] Shankar, G.M., Bloodgood, B.L., Townsend, M., Walsh, D.M., Selkoe, D.J. and Sabatini, B.L. (2007) Natural Oligomers of the Alzheimer Amyloid- $\beta$ Protein Induce Reversible Synapse Loss by Modulating an NMDA-Type Glutamate Receptor-Dependent Signaling Pathway. The Journal of Neuroscience, 27, 2866-2875. http://dx.doi.org/10.1523/JNEUROSCI.4970-06.2007

[12] Desai, A.K. and Chand, P. (2009) Tau-Based Therapies for Alzheimer's Disease: Wave of the Future. Primary Psychiatry, 16, 40-46.

[13] Kolarova, M., García-Sierra, F., Bartos, A., Ricny, J. and Ripova, D. (2012) Structure and Pathology of Tau Protein in Alzheimer Disease. International Journal of Alzheimer's Disease, 2012, 1-13. http://dx.doi.org/10.1155/2012/731526

[14] Tuneu Valls, L., Cano, M.R., Marquillas, M.S., Pérez, E.P. and Franco, A.G. (2015) Guía de seguimiento farmacoterapéutico de los pacientes con Alzheimer. http://www.ugr.es/cts131/esp/guias/Guia_Alzheimer.pdf

[15] Williams, D.R. (2006) Tauopathies: Classification and Clinical Update on Neurodegenerative Diseases Associated with Microtubule-Associated Protein Tau. Internal Medicine Journal, 36, 652-660. http://dx.doi.org/10.1111/j.1445-5994.2006.01153.x

[16] Ferri, C.P., Prince, M., Brayne, C., Brodaty, H., Fratiglioni, L., et al. (2006) Global Prevalence of Dementia: A Delphi Consensus Study. The Lancet, 366, 2112-2117.

[17] Brookmeyer, R., Johnson, E., Ziegler-Graham, K. and Arrighi, H.M. (2007) Forecasting the Global Burden of Alzheimer's Disease. Alzheimer's \& Dement, 3, 186-191. http://dx.doi.org/10.1016/j.jalz.2007.04.381

[18] Spuch, C., Saida, O. and Navarro, C. (2012) Advances in the Treatment of Neurodegenerative Disorders Employing Nanoparticles. Recent Patents on Drug Delivery \& Formulation, 6, 2-18. http://dx.doi.org/10.2174/187221112799219125

[19] Food and Drug Administration. http://www.fda.gov/Drugs/default.htm

[20] Romero, A., Cacabelos, R., Oset-Gasque, M.J., Samadi, A. and Marco-Contelles, J. (2013) Novel Tacrine-Related Drugs as Potential Candidates for the Treatment of Alzheimer's Disease. Bioorganic \& Medicinal Chemistry Letters, 23, 1916-1922. http://dx.doi.org/10.1016/j.bmcl.2013.02.017

[21] Watkins, P.B., Zimmerman, H.J., Knapp, M.J., Gracon, S.I. and Lewis, K.W. (1994) Hepatotoxic Effects of Tacrine Administration in Patients with Alzheimer's Disease. Jama, 271, 992-998. http://dx.doi.org/10.1001/jama.1994.03510370044030

[22] Johnson, J.W. and Kotermanski, S.E. (2006) Mechanism of Action of Memantine. Current Opinion in Pharmacology, 6, 61-67. http://dx.doi.org/10.1016/j.coph.2005.09.007

[23] Tetsuya, K., Daniel, J., Jihoon Jo, W., Regan, P., Piers, T., et al. (2014) Microtubule-Associated Protein Tau Is Essential for Long-Term Depression in the Hippocampus. Philosophical Transactions of the Royal Society B: Biological Sciences, 369, 20130144. http://dx.doi.org/10.1098/rstb.2013.0144

[24] Mangialasche, F., Solomon, A., Winblad, B., Mecocci, P. and Kivipelto, M. (2010) Alzheimer's Disease: Clinical Trials and Drug Development. The Lancet Neurology, 9, 702-716. http://dx.doi.org/10.1016/S1474-4422(10)70119-8

[25] Hurd, M.D., Martorell, P., Delavande, A., Mullen, K.J. and Langa, K.M. (2013) Monetary Costs of Dementia in the 
United States. New England Journal of Medicine, 368, 1326-1334. http://dx.doi.org/10.1056/NEJMsa1204629

[26] Alzheimer’s Association (2015) Alzheimer’s Disease Facts and Figures. Alzheimer’s \& Dementia, 11, 1-83.

[27] Umira, S.A. (2015) “Alzheimer” an Ambiguous Ailment; a Comprehensive Review. Research \& Reviews: A Journal of Pharmaceutical Science, 5, 8-16.

[28] Huang, Y. and Mucke, L. (2012) Alzheimer Mechanisms and Therapeutic Strategies. Cell, 148, 1204-1222. http://dx.doi.org/10.1016/J.Cell.2012.02.040

[29] Israel, M.A., Yuan, S.H., Bardy, C., Reyna, S.M., Ma, Y., et al. (2012) Probing Sporadic and Familial Alzheimer's Disease Using Induced Pluripotent Stem Cells. Nature, 482, 216-220.

[30] Lindvall, O. and Kokaia, Z. (2006) Stem Cells for the Treatment of Neurological Disorders. Nature, 441, $1094-1096$. http://dx.doi.org/10.1038/nature04960

[31] Yagi, T., Ito, D., Okada, Y., Akamatsu, W., Nihei, Y., et al. (2011) Modeling Familial Alzheimer’s Disease with Induced Pluripotent Stem Cells. Human Molecular Genetics, 20, 4530-4539. http://dx.doi.org/10.1093/hmg/ddr394

[32] Lee, H.J., Lee, J.K., Lee, H., Shin, J.W., Carter, J.E., Sakamoto, T., Jin, H.K. and Bae, J.S. (2010) The Therapeutic Potential of Human Umbilical Cord Blood-Derived Mesenchymal Stem Cells in Alzheimer's Disease. Neuroscience Letters, 481, 30-35. http://dx.doi.org/10.1016/j.neulet.2010.06.045

[33] Lindvall, O. and Kokaia, Z. (2010) Stem Cells in Human Neurodegenerative Disorders-Time for Clinical Translation? The Journal of Clinical Investigation, 120, 29. http://dx.doi.org/10.1172/jci40543

[34] Müller, F.J., Snyder, E.Y. and Loring, J.F. (2006) Gene Therapy: Can Neural Stem Cells Deliver? Nature Reviews Neuroscience, 7, 75-84. http://dx.doi.org/10.1038/nrn1829

[35] Tuszynski, M.H. and Blesch, A. (2004) Nerve Growth Factor: From Animal Models of Cholinergic Neuronal Degeneration to Gene Therapy in Alzheimer's Disease. Progress in Brain Research, 146, 439-449. http://dx.doi.org/10.1016/S0079-6123(03)46028-7

[36] Nagahara, A.H., Merrill, D.A., Coppola, G., Tsukada, S., Schroeder, B.E., et al. (2009) Neuroprotective Effects of Brain-Derived Neurotrophic Factor in Rodent and Primate Models of Alzheimer's Disease. Nature Medicine, 15, 331337. http://dx.doi.org/10.1038/nm.1912

[37] Macdonald, A., Briggs, K., Poppe, M., Higgins, A., Velayudhan, L. and Lovestone, S. (2008) A Feasibility and Tolerability Study of Lithium in Alzheimer's Disease. International Journal of Geriatric Psychiatry, 23, 704-711. http://dx.doi.org/10.1002/gps.1964

[38] Toledo, E.M. and Inestrosa, N.C. (2010) Activation of Wnt Signaling by Lithium and Rosiglitazone Reduced Spatial Memory Impairment and Neurodegeneration in Brains of an APPswe/PSEN1 $\Delta$ E9 Mouse Model of Alzheimer’s Disease. Molecular Psychiatry, 15, 272-285. http://dx.doi.org/10.1038/mp.2009.72

[39] Forlenza, O.V., De-Paula, V.D.J.R. and Diniz, B.S.O. (2014) Neuroprotective Effects of Lithium: Implications for the Treatment of Alzheimer's Disease and Related Neurodegenerative Disorders. ACS Chemical Neuroscience, 5, 443-450. http://dx.doi.org/10.1021/cn5000309

[40] Wolozin, B., Wang, S.W., Li, N.C., Lee, A., Lee, T.A. and Kazis, L.E. (2007) Simvastatin Is Associated with a Reduced Incidence of Dementia and Parkinson's Disease. BMC Medicine, 5, 20. http://dx.doi.org/10.1186/1741-7015-5-20

[41] Shepardson, N.E., Shankar, G.M. and Selkoe, D.J. (2011) Cholesterol Level and Statin Use in Alzheimer Disease: II. Review of Human Trials and Recommendations. Archives of Neurology, 68, 1385-1392.

http://dx.doi.org/10.1001/archneurol.2011.242

[42] Kandiah, N. and Feldman, H.H. (2009) Therapeutic Potential of Statins in Alzheimer's Disease. Journal of the Neurological Sciences, 283, 230-234. http://dx.doi.org/10.1016/j.jns.2009.02.352

[43] Lemere, C.A. (2009) Developing Novel Immunogens for a Safe and Effective Alzheimer's Disease Vaccine. Progress in Brain Research, 175, 83-93. http://dx.doi.org/10.1016/S0079-6123(09)17506-4

[44] Wisniewski, T. and Konietzko, U. (2008) Amyloid- $\beta$ Immunisation for Alzheimer's Disease. The Lancet Neurology, 7, 805-811. http://dx.doi.org/10.1016/S1474-4422(08)70170-4

[45] Davtyan, H. and Konietzko, U. (2013) Immunogenicity, Efficacy, Safety, and Mechanism of Action of Epitope Vaccine (Lu AF20513) for Alzheimer's Disease: Prelude to a Clinical Trial. The Journal of Neuroscience, 33, 4923-4934. http://dx.doi.org/10.1523/JNEUROSCI.4672-12.2013

[46] Rottkamp, C.A., Nunomura, A., Raina, A.K., Sayre, L.M., Perry, G. and Smith, M.A. (2000) Oxidative Stress, Antioxidants, and Alzheimer Disease. Alzheimer Disease \& Associated Disorders, 14, S62-S66. http://dx.doi.org/10.1097/00002093-200000001-00010

[47] Galasko, D.R., Peskind, E., Clark, C.M., Quinn, J.F., Ringman, J.M., Jicha, G.A. and Aisen, P. (2012) Antioxidants for 
Alzheimer Disease: A Randomized Clinical Trial with Cerebrospinal Fluid Biomarker Measures. Archives of Neurology, 69, 836-841. http://dx.doi.org/10.1001/archneurol.2012.85

[48] Rege, S.D., Geetha, T., Broderick, T.L. and Ramesh Babu, J. (2015) Resveratrol Protects $\beta$ Amyloid-Induced Oxidative Damage and Memory Associated Proteins in H19-7 Hippocampal Neuronal Cells. Current Alzheimer Research, 12, 147-156. http://dx.doi.org/10.2174/1567205012666150204130009

[49] Pillai, R., Uyehara-Lock, J.H. and Bellinger, F.P. (2014) Selenium and Selenoprotein Function in Brain Disorders. IUBMB Life, 66, 229-239. http://dx.doi.org/10.1002/iub.1262

[50] de Oliveira, B.F., Veloso, C.A., Nogueira-Machado, J.A., de Moraes, E.N., dos Santos, R.R., Cintra, M.T.G. and Chaves, M.M. (2012) Ascorbic Acid, Alpha-Tocopherol, and Beta-Carotene Reduce Oxidative Stress and Proinflammatory Cytokines in Mononuclear Cells of Alzheimer’s Disease Patients. Nutritional Neuroscience, 15, 244-251. http://dx.doi.org/10.1179/1476830512Y.0000000019

[51] Mangialasche, F., Kivipelto, M., Mecocci, P., Rizzuto, D., Palmer, K., Winblad, B. and Fratiglioni, L. (2010) High Plasma Levels of Vitamin E Forms and Reduced Alzheimer's Disease Risk in Advanced Age. Journal of Alzheimer's Disease, 20, 1029-1037.

[52] Carroll, J.C., Rosario, E.R., Chang, L., Stanczyk, F.Z., Oddo, S., LaFerla, F.M. and Pike, C.J. (2007) Progesterone and Estrogen Regulate Alzheimer-Like Neuropathology in Female 3xTg-AD Mice. The Journal of Neuroscience, 27, 13357-13365.

[53] Lee, J.H., Jiang, Y., Han, D.H., Shin, S.K., Choi, W.H. and Lee, M.J. (2014) Targeting Estrogen Receptors for the Treatment of Alzheimer's Disease. Molecular Neurobiology, 49, 39-49. http://dx.doi.org/10.1007/s12035-013-8484-9

[54] Vest, R.S. and Pike, C.J. (2013) Gender, Sex Steroid Hormones, and Alzheimer's Disease. Hormones and Behavior, 63, 301-307. http://dx.doi.org/10.1016/j.yhbeh.2012.04.006

[55] Xia, W. (2001) Amyloid Metabolism and Secretases in Alzheimer's Disease. Current Neurology and Neuroscience Reports, 1, 422-427. http://dx.doi.org/10.1007/s11910-001-0101-z

[56] Holsinger, R.M., McLean, C.A., Beyreuther, K., Masters, C.L. and Evin, G. (2002) Increased Expression of the Amyloid Precursor $\beta$-Secretase in Alzheimer's Disease. Annals of Neurology, 51, 783-786. http://dx.doi.org/10.1002/ana.10208

[57] Yan, R. and Vassar, R. (2014) Targeting the $\beta$ Secretase BACE1 for Alzheimer's Disease Therapy. The Lancet Neurology, 13, 319-329. http://dx.doi.org/10.1016/S1474-4422(13)70276-X

[58] Maiti, P., Manna, J., Veleri, S. and Frautschy, S. (2014) Molecular Chaperone Dysfunction in Neurodegenerative Diseases and Effects of Curcumin. BioMed Research International, 2014, Article ID: 495091. http://dx.doi.org/10.1155/2014/495091

[59] Ono, K., Hasegawa, K., Naiki, H., Naiki and Yamada, M. (2004) Curcumin Has Potent Anti-Amyloidogenic Effects for Alzheimer's $\beta$-Amyloid Fibrils in Vitro. Journal of Neuroscience Research, 75, 742-750. http://dx.doi.org/10.1111/j.1445-5994.2006.01153.x

[60] Hamaguchi, T., Ono, K. and Yamada, M. (2010) Review: Curcumin and Alzheimer's Disease. CNS Neuroscience \& Therapeutics, 16, 285-297. http://dx.doi.org/10.1111/j.1755-5949.2010.00147.x

[61] Lim, G.P., Calon, F., Morihara, T., Yang, F., Teter, B., Ubeda, O. and Cole, G.M. (2005) A Diet Enriched with the Omega-3 Fatty Acid Docosahexaenoic Acid Reduces Amyloid Burden in an Aged Alzheimer Mouse Model. The Journal of Neuroscience, 25, 3032-3040. http://dx.doi.org/10.1523/JNEUROSCI.4225-04.2005

[62] Calon, F., Lim, G. P., Yang, F., Morihara, T., Teter, B., Ubeda, O. and Cole, G.M. (2004) Docosahexaenoic Acid Protects from Dendritic Pathology in an Alzheimer’s Disease Mouse Model. Neuron, 43, 633-645. http://dx.doi.org/10.1016/j.neuron.2004.08.013

[63] Hashimoto, M., Hossain, S., Katakura, M., Al Mamun, A. and Shido, O. (2015) The Binding of A $\beta$ 1-42 to Lipid Rafts of RBC Is Enhanced by Dietary Docosahexaenoic Acid in Rats: Implicates to Alzheimer's Disease. Biochimica et Biophysica Acta (BBA)-Biomembranes, 1848, 1402-1409. http://dx.doi.org/10.1016/j.bbamem.2015.03.008

[64] Qing, H., He, G., Ly, P.T., Fox, C.J., Staufenbiel, M., Cai, F. and Song, W. (2008) Valproic Acid Inhibits A $\beta$ Production, Neuritic Plaque formation, and Behavioral Deficits in Alzheimer’s Disease Mouse Models. The Journal of Experimental Medicine, 205, 2781-2789. http://dx.doi.org/10.1084/jem.20081588

[65] Smith, A.M., Gibbons, H.M. and Dragunow, M. (2010) Valproic Acid Enhances Microglial Phagocytosis of Amyloid$\beta$ 1-42. Neuroscience, 169, 505-515. http://dx.doi.org/10.1016/j.neuroscience.2010.04.041

[66] Ziyatdinova, S., Viswanathan, J., Hiltunen, M., Tanila, H. and Pitkänen, A. (2015) Reduction of Epileptiform Activity by Valproic Acid in a Mouse Model of Alzheimer's Disease Is Not Long-Lasting after Treatment Discontinuation. Epilepsy Research, 112, 43-55. http://dx.doi.org/10.1016/j.eplepsyres.2015.02.005

[67] Dekosky, S.T., Williamson, J.D., Fitzpatrick, A.L., Kronmal, R.A., Ives, D.G., Saxton, J.A., et al. (2008) Ginkgo Bi- 
loba for Prevention of Dementia: A Randomized Controlled Trial. Jama, 300, 2253-2262. http://dx.doi.org/10.1001/jama.2008.683

[68] Vellas, B., Coley, N., Ousset, P.J., Berrut, G., Dartigues, J.F. and Dubois, B., GuidAge Study Group (2012) LongTerm Use of Standardised Ginkgo Biloba Extract for the Prevention of Alzheimer's Disease (GuidAge): A Randomised Placebo-Controlled Trial. The Lancet Neurology, 11, 851-859. http://dx.doi.org/10.1016/S1474-4422(12)70206-5

[69] Ude, C., Schubert-Zsilavecz, M. and Wurglics, M. (2013) Ginkgo Biloba Extracts: A Review of the Pharmacokinetics of the Active Ingredients. Clinical Pharmacokinetics, 52, 727-749. http://dx.doi.org/10.1007/s40262-013-0074-5 